\begin{tabular}{|c|c|}
\hline $\begin{array}{l}\text { MINING AND METALLURGY INSTITUTE BOR } \\
\text { UDK: } 622\end{array}$ & $\begin{array}{l}\text { ISSN: 2334-8836 (Štampano izdanje) } \\
\text { ISSN: 2406-1395 (Online) }\end{array}$ \\
\hline UDK: 541.49(282.4):504.06:526.8(045)=111 & DOI:10.5937/MMEB1502113G \\
\hline \multicolumn{2}{|c|}{ Vojin Gordanić, Milka Vidović, Ivana Trajković", Saša Rogan ${ }^{*}$} \\
\hline $\begin{array}{r}\text { GEOCHEMICAL MAPPI } \\
\text { THE BASIN AREA OF THE R } \\
\text { THE GEOCHEMICAL B }\end{array}$ & $\begin{array}{l}\text { NK PROFILES IN } \\
\text { LE IN ESTABLISHING } \\
\text { ASSESSMENT OF }\end{array}$ \\
\hline
\end{tabular}

\begin{abstract}
Geochemical mapping of riverbank profiles of the basin area of the river Ibar was performed in the purpose of making regional geochemical map of Serbia 1:1000000. In this area, deposits of lead and zinc are located, and they are characterized by very complex geological composition. Sampling net at chosen locations of riverbank profiles was adjusted to the morphological and hydrographic characteristics of the terrain. At every profile, samples were collected from A-horizon, Ob-overbank sediment and S-active stream sediment, while tracking the changes of lithological members, in accordance to the WEGS methodology (Western European Geological Surveys).

The preserved geochemical track in the overbank sediment is of special significance for correlation the results of chemical elements in the surface part of (A-horizon) and active contemporary stream sediment. In the analytical process, beside determining contents of $\mathrm{Pb}, \mathrm{Zn}, \mathrm{Cu}, \mathrm{Co}, \mathrm{Ni}, \mathrm{Cr}, \mathrm{Sb}, \mathrm{V}, \mathrm{Cd}$ and other elements, the radiometric examinations of contents of $U^{238}, T^{232}$ and $K^{40}$, were also conducted as well as the appropriate sedimentological analyses. On the basis of geochemical prospection results, a data base was formed which represents a foundation for estimation of anthropogenic influence on the living environment of rural settlements in the basin area of the river Ibar. In accordance to the geological-structural and morphological characteristics of the terrain, the results are applicable in the research of mineral raw materials, in agriculture, forestry, geomedicine, etc.
\end{abstract}

Keywords: overbank, strim sediments, A-horizotn, geochemical mapping, riverbank profile

\title{
INTRODUCTION
}

The overbank sediment (material deposited in the alluvial plain outside of the drainage canal) is usually used in the processes of making regional geochemical maps [1]. Studies in Great Britain showed a "close link" between the mine contamination and contents of metals in the contemporary overbank sediments [2,3]. Application of OB-overbank sediment as a medium suitable for making geochemical atlas of Western

Europe and defining the anthropogenic influence on the living environment was supported by Bolviken et al. [4]. For making a regional geochemical map of Serbia 1:1000000 [5], the overbank sediment was used, and for researches basin areas from 60$600 \mathrm{~km}^{2}$ were used. The significance of overbank sediment in defining the ecological status and making regional geochemical map of Serbia is shown at locations of

\footnotetext{
* University of Belgrade, Scientific Institution Institute of Chemistry, Technology and Metallurgy, Department for Ecology and Technoeconomics, Njegoševa 12, Belgrade, e-mail: trajkovicivana@yahoo.com

** This work was supported by the Ministry of Education, Science and Technological Development of the Republic of Serbia (Project OI 176018: "Geological and Ecotoxicological Research in Identification of Geopathogenic Zones of Toxic Elements in Drinking Water Reservoirs - Analysis of Methods and Procedures for Reduction the effects of Biogeochemical Anomalies ").
} 
riverbank profiles (A-horizon, OB-overbank sediment and $\mathrm{S}$-stream sediment) $[6,7,8]$. Since the riverbank sediments are used, beside in the process of making regional geochemical map, also in defining the anthropogenic influence on the living environment, the WEST methodology (Western European Geological Surveys) is usually used in researches. Due to these reasons, the basin area of the river Ibar was selected, where deposits of lead and zinc were located, which are characterized by very complex geological composition. Geochemical mapping the riverbank profiles of the river Ibar basin, included the part of the Vardar zone area and inner Dinarides. Two complexes stand out: the Volcanic zone of Kopaonik and the area of mountain Rogozna.

The volcanic zone of Kopaonik is located on the both sides of the river Ibar, in length of about $60 \mathrm{~km}$ and width of $35 \mathrm{~km}$ (direction of extending (NNW - SSE), including the area from the mouth in West Morava in the north till Leposavić in the south. It continues onto volcanogenic complex of the mines of $\mathrm{Pb}$ and $\mathrm{Zn}$ "Trepča". Volcanic activity took place in three phases: preplutonic phase - dalto-andesites, followed by larger occurrences of volcanic breccias, tuffs and tuffites; sinplutonic phasegrano- diorites, quartzmonzonites and quartzdiorites with occurrences of volcanic breccias, tuffs and tuffites and postplutonic phase - basalts and andesite basalts. Volcanics and pyroclastices of Rogozna are different from Kopaonik's by younger postplicative phases of volcanic activity. Among larger structural forms, the structural zone of Studenica is of relevance, whose system of ruptures goes along with the flow of the river Studenica (tributary of Ibar), and it is difficult to follow it in the Ibar ultramaphite complex.

\section{MATHERIALS AND METHODS}

The basin area of the river Ibar with its tributaries - rivers Ribnica, Lopatnica, Studenica, Raška, Ljudska, Jošanica, Drenska, Kozareva, Vidrenjak, covers the area of about $7000 \mathrm{~km}^{2}$. In the phase of regional geochemical prospection, mapping of riverbank profiles of alluvial plains and river valleys in the part of southern and central Serbia was conducted. Sampling net was adjusted to the morphological and hydrographic characteristics of the terrain, in accordance to the map scale 1:1000000 (Figure 1).

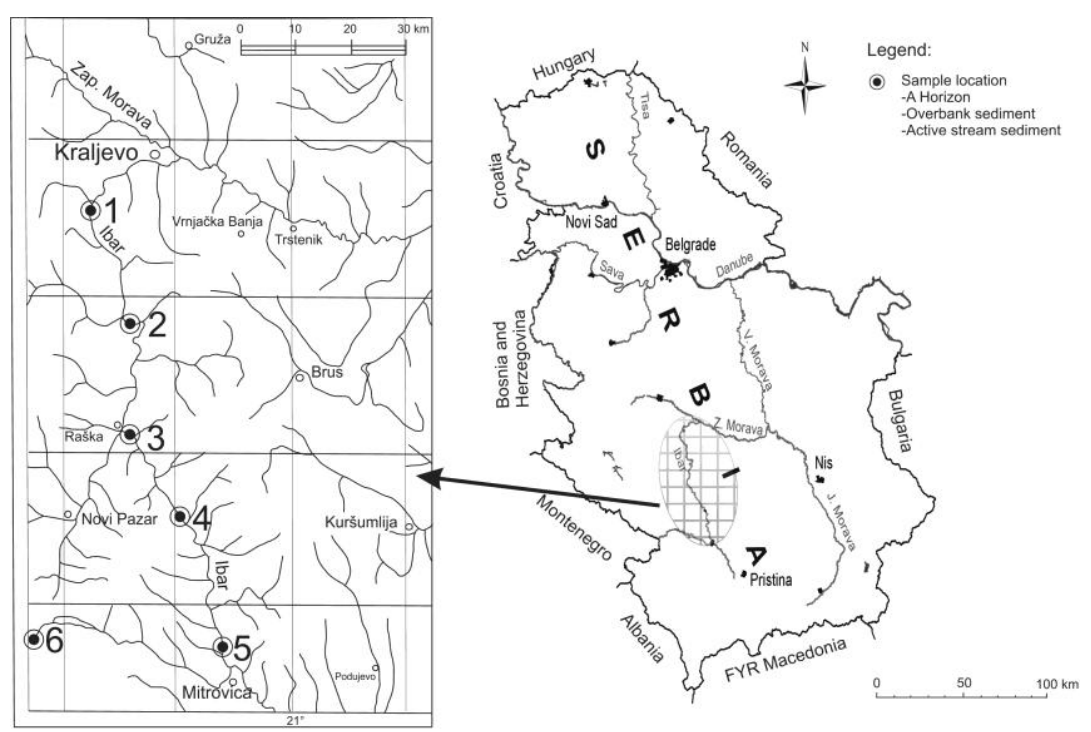

Figure 1 Geochemical map with the sample locations 
According to the WEGS recommendation, at selected locations (shown in Figure 1), samples were collected from:

- A - horizon, at depth up to $20 \mathrm{~cm}$ close to surface, which is polluted by the human impact, weight $5 \mathrm{~kg}$;

- Subsurface material "overbank sediment" sampled at depth of $1-1,5 \mathrm{~m}$, in accordance to the lithological changes of deposited sediments, weight 5-15 kg;

- Contemporary active stream sediment, weight $5 \mathrm{~kg}$, for correlation with the results from overbank sediments, formed in the preindustrial era.

The samples were dried at temperature of $80{ }^{\circ} \mathrm{C}$ and sieved through sieves dimensions up to $2 \mathrm{~mm}$; $0.5-2 \mathrm{~mm}$; $0.5-0.18 \mathrm{~mm}$; $0.18-0.125 \mathrm{~mm}$. For fractions sma-ller than $0.125 \mathrm{~mm}$, laboratory tests were conducted. Chemical analyses methods that were applied are: Atomic Absorption Spectrophotometry (AAS) and Inducted Coupled Plasma-Atomic-Emission Spectrophotometry (ICP-AES). Samples were prepared by open digestion with mineral acids: with "aqua regia" (mixture $\mathrm{HCl}: \mathrm{NO}_{3}=3: 1$ ) for: $\mathrm{Ag}$, $\mathrm{Au}$, $\mathrm{Bi}, \mathrm{Cd}, \mathrm{Co}, \mathrm{Cu}, \mathrm{Mo}, \mathrm{Ni}, \mathrm{Pb}, \mathrm{Sb}, \mathrm{V}$ and $\mathrm{Zn}$; with "modified aqua regia" for: $\mathrm{P}$ and $\mathrm{S}$; and separation with $\mathrm{HF}, \mathrm{NH} 3$ and $\mathrm{HClO}_{4}$ for: $\mathrm{B}, \mathrm{Ba}, \mathrm{Be}, \mathrm{Cr}, \mathrm{Cs}, \mathrm{Li}, \mathrm{Rb}$ and $\mathrm{Sr}$.

The international geochemical standards of granite G-1 and diabase W-1 were used in the analytical process, and the samples were also checked in the other laboratories as well. In all samples sedimentological, spectrochemical, radiometric and partially mineralogical researches were performed. In collected samples with low content of $\mathrm{U}(<$ $50 \mathrm{ppm})$, contents of total $\mathrm{U},{ }^{232} \mathrm{Th}$ and ${ }^{40} \mathrm{~K}$ were determined. Measurements were conducted using a scintilation detector 4" $\mathrm{x} 4$ ", of Bikron company with crystal made of $\mathrm{NaI}$ with multiplicative analyzer (MCA; 4096 channels) type "ORTEC-7500". The analyses are based on the measurements of high energy radiations (0-3 meV). For calibration of the spectrum and calculation of natural radionuclides concentration, the standards of uranium ore (U) and thorium (Th) were used, "New Bruncvick Laboratory" (USAEC), NBL. No. 103 0.005\%, NBL. No. 107 0.10\% Th. Potassium chloride was used (r.a.) as the standard for potassium.

\section{RESULTS AND DISCUSSION}

In accordance to the geological characteristics of the terrain in the riverbank profile, the geochemical track of elements which reflect the composition of the spring material which is deposited in the fluvial plain of the basin area of the river Ibar, is preserved. On the basis of the results of granulometric examinations the collected sediments of deposit of selected locations were determined according to classification of Folk, 1954 [9] (Figure 2):

- A - horizon as: sandy alevrite, alevrite sand, sand, alevrite sandy gravel;

- OB - overbank sediment as: sandy alevrite, alevrite sand, gravelly alevrite sand, sand;

- S - stream sediment as: gravelly alevrite sand, gravelly sand, sandy gravel, coarse-grained sand, gravel.

The geochemical track of riverbank profiles at selected locations: 1, 2, 3, 4, 5, 6 is shown in Table 1 and sampling places are presented in a geochemical map ( $\mathrm{Fi}$ gure 1). 


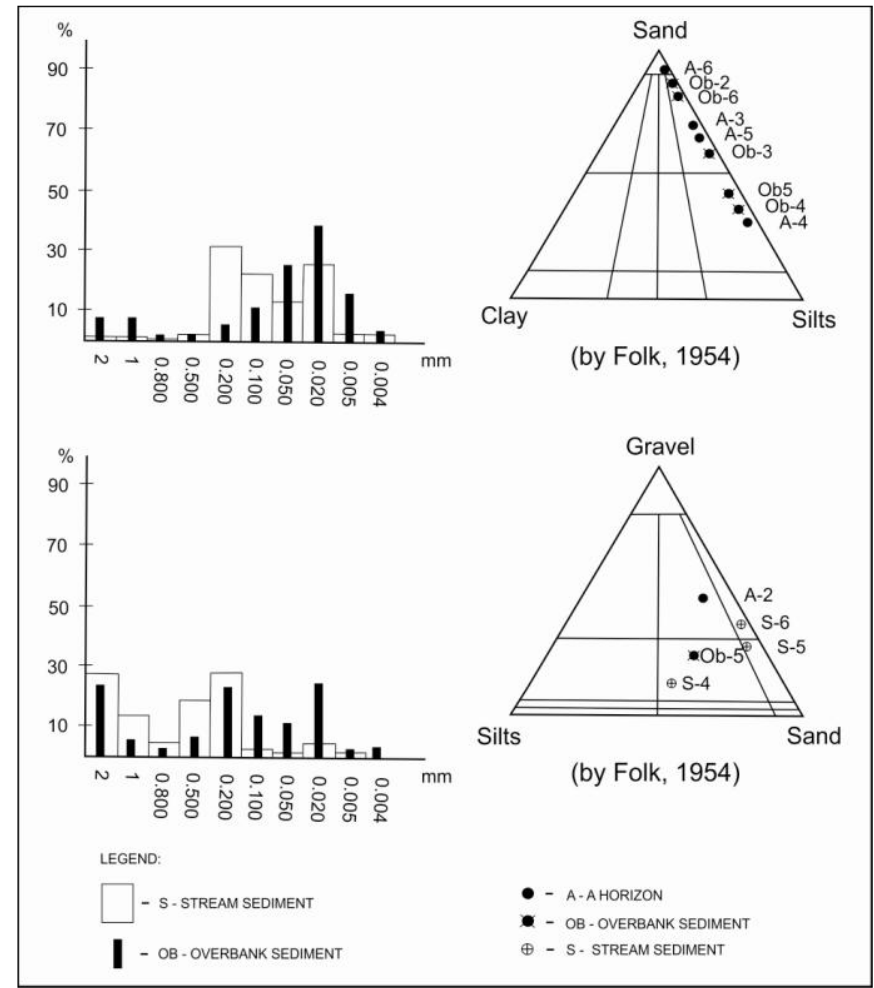

Figure 2 Histogram-fraction distribution in profile of the river Ibar and Folk classification [9]

Table 1 Contents of elements in the riverbank profiles from the spring part of the river Ibar (location 6) till the mouth in the West Morava (location 1)

\begin{tabular}{|c|c|c|c|c|c|c|c|c|}
\hline \multicolumn{2}{|c|}{ River Ibar } & $\begin{array}{l}\text { Pb, } \\
\text { ppm }\end{array}$ & $\begin{array}{l}\text { Zn, } \\
\text { ppm }\end{array}$ & $\begin{array}{l}\mathrm{Cu}, \\
\text { ppm }\end{array}$ & $\begin{array}{l}\text { Cd, } \\
\text { ppm }\end{array}$ & $\begin{array}{l}\text { As, } \\
\text { ppm }\end{array}$ & $\begin{array}{c}\text { Fe, } \\
\text { ppm }\end{array}$ & $\begin{array}{l}\text { Uu, } \\
\text { ppm }\end{array}$ \\
\hline \multirow{3}{*}{ Location 1} & $\overline{\mathbf{A}}$ & 173 & 276 & 32 & 0.9 & - & - & - \\
\hline & OB & 190 & 1333 & 28 & 3.3 & - & - & - \\
\hline & $\mathbf{S}$ & 127 & 1220 & 27 & 3.6 & - & - & - \\
\hline \multirow{3}{*}{ Location 2} & A & 85 & 65 & 35 & 1.2 & 13.9 & 31400 & 4.6 \\
\hline & OB & 95 & 78 & 35 & 1.3 & 9.8 & 35700 & 4.8 \\
\hline & $\mathbf{S}$ & 90 & 81 & 35 & 1.3 & 11.6 & 42800 & 4.0 \\
\hline \multirow{3}{*}{ Location 3} & $\mathbf{A}$ & 110 & 81 & 35 & 0.9 & 8.8 & 22500 & 5.6 \\
\hline & OB & 110 & 25 & 35 & 0.6 & 11.5 & 18700 & 9.8 \\
\hline & $\mathbf{S}$ & 60 & 72 & 35 & 1.2 & 8.2 & 25000 & 18.2 \\
\hline \multirow{3}{*}{ Location 4} & $\mathbf{A}$ & 210 & 311 & 68 & 1 & 3.5 & 70525 & 3.5 \\
\hline & OB & 390 & 392 & 61 & 2 & 7.8 & 72540 & 3.5 \\
\hline & $\mathbf{S}$ & 530 & 712 & 100 & 4 & 17.4 & 76895 & 3.2 \\
\hline \multirow{4}{*}{ Location 5} & A & 3500 & 3710 & 345 & 26 & 78.8 & 150150 & 0.4 \\
\hline & OB & 4000 & 297 & 491 & 11 & 36.3 & 241800 & - \\
\hline & OB & 3070 & 4995 & 542 & 26 & 112 & 108875 & 4.2 \\
\hline & $\mathbf{S}$ & 700 & 1703 & 79 & 13 & 7.5 & 80145 & 7.7 \\
\hline \multirow{3}{*}{ Location 6} & $\mathbf{A}$ & 85 & 99 & 68 & 1 & 10.1 & 59020 & 3.0 \\
\hline & OB & 35 & 101 & 47 & $\square 1$ & 7.0 & 45045 & 6.7 \\
\hline & $\mathbf{S}$ & 100 & 88 & 44 & 1.0 & 3.2 & 34250 & 3.2 \\
\hline
\end{tabular}


The results of contents variations of $\mathrm{Pb}, \mathrm{Zn}, \mathrm{Cu}, \mathrm{Cd}$, As are shown in diagrams for every riverbank profile per locations for A-horizon, OB-overbank sediment and S-stream sediment (Figures 3 - 6).

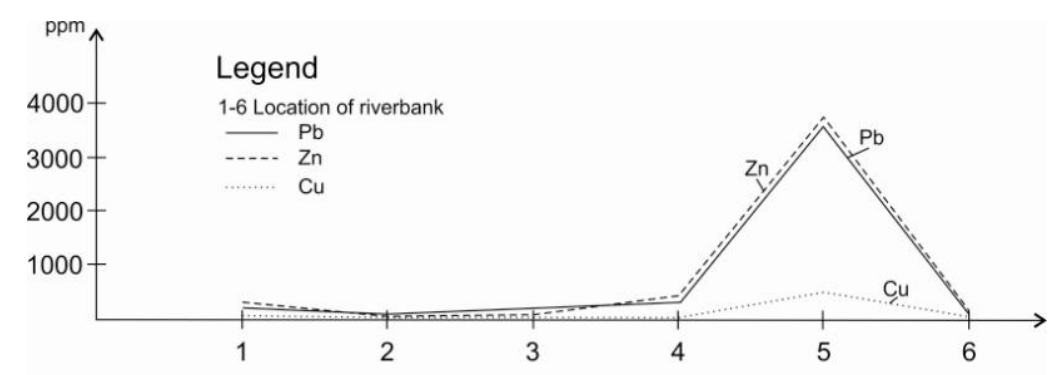

Figure 3 Content variations of $\mathrm{Pb}, \mathrm{Zn}$ and $\mathrm{Cu}$ in A-horizon at locations of the river Ibar

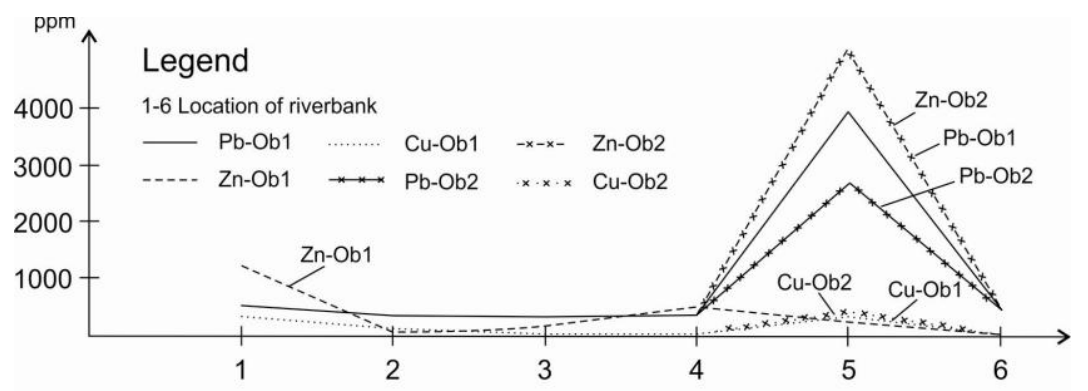

Figure 4 Content variations of $\mathrm{Pb}, \mathrm{Zn}$ and $\mathrm{Cu}$ in OB-overbank sediments of the river Ibar

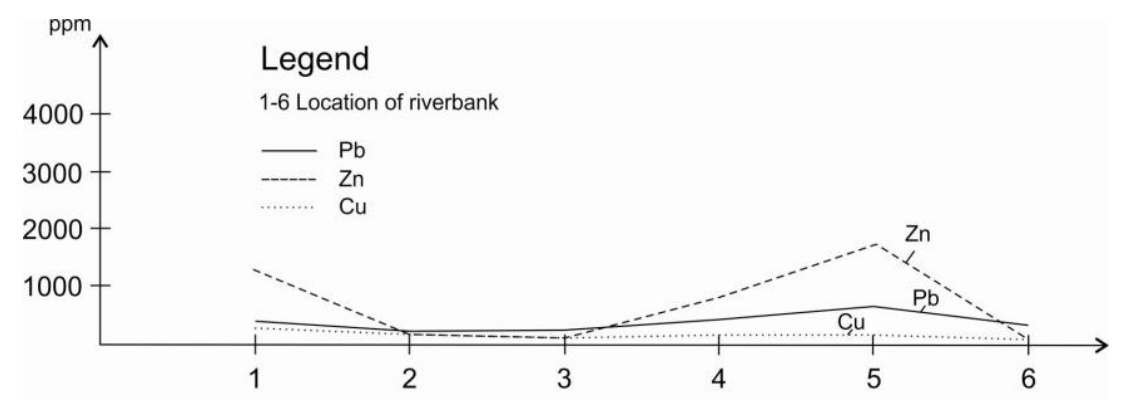

Figure 5 Content variations of $\mathrm{Pb}, \mathrm{Zn}$ and $\mathrm{Cu}$ in $\mathrm{S}$-stream sediments of the river Ibar

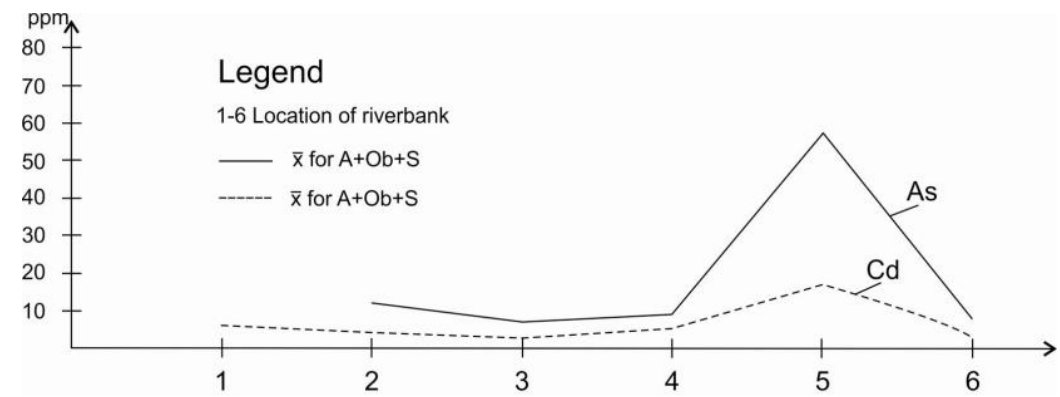

Figure 6 Content variations of As and Cd in the riverbank profiles of the river Ibar 
Anomaly concentrations of $\mathrm{Pb}, \mathrm{Zn}, \mathrm{Cu}$, $\mathrm{Cd}$, As and $\mathrm{Fe}$ are of twofold origin: from rocks in which there is a fon of high values (Table 2) and elements which origi nate from ore (ore halda, old mining works), metallurgy processes, agrochemical compounds rich in metals, material for filling the roads, wastewater and other.

Table 2 Average contrast among the metal contents in the zone without ores and in the peripheral ore

\begin{tabular}{|l|c|c|c|}
\hline \multicolumn{1}{|c|}{ Main metals } & $\begin{array}{c}\text { (A) Content in magmat- } \\
\text { ic rocks, } \mathbf{~ p p m}\end{array}$ & $\begin{array}{c}\text { (B) Content in the ores that are } \\
\text { being processed, ppm }\end{array}$ & $\begin{array}{c}\text { Contrast ratio } \\
(\mathbf{B} / \mathbf{A})\end{array}$ \\
\hline Lead, $\mathrm{Pb}$ & $16^{\mathrm{a}}$ & $50000^{\mathrm{b}}$ & 3000 \\
\hline Zinc, $\mathrm{Zn}$ & $80^{\mathrm{a}}$ & $80000^{\mathrm{b}}$ & 1000 \\
\hline $\mathrm{Copper}, \mathrm{Cu}$ & $70^{\mathrm{a}}$ & $10000^{\mathrm{b}}$ & 140 \\
\hline Chrome, $\mathrm{Cr}$ & $2000^{\mathrm{c}}$ & $250000^{\mathrm{b}}$ & 125 \\
\hline Nickel, $\mathrm{Ni}$ & $160^{\mathrm{d}}$ & $15000^{\mathrm{b}}$ \\
\hline \\
${ }^{\mathrm{a}}[10]$ \\
${ }^{\mathrm{b}}$ Data for Pb, Zn, Cu [11] \\
${ }^{\mathrm{c}}$ Medium content in ultrabasic rocks [12] \\
${ }^{\mathrm{d}}$ Medium content in gabbro [13]
\end{tabular}

Contrasts in the metal contents between the secondary geochemical anomalies and normal fon depend on many factors: contrast between ore and surrounding rock, relative mobility of elements in scattering environment, concentration dilution by sterile material. For different types of mineral deposits, the primary contrast varies in wide limits (Table 2). The primary contrast is more sustained by immobile elements $(\mathrm{Pb})$ than mobile elements $(\mathrm{Zn}, \mathrm{Cu}$ and $\mathrm{U})$, which are subjected to leaching, whose level is determined by decay intensity, velocity of water movement, $\mathrm{pH}$ value and many other factors which influence on the form of scattering. In water, contrast is also in the function of mobility [13]. The most mobile elements show the biggest contrast. Mobile elements which deposit at relatively small changes of chemical and biological conditions show the most severe contrast in hydromorphic anomalies of soil and sediments [14].

In the prospected area of the river Ibar basin, the main rocks of high fon values are located. The most distinctive is a group of ultrabasic rocks (peridotites, serpetinites) with high contents of $\mathrm{Cr}, \mathrm{Ni}, \mathrm{Co}$ and $\mathrm{Mg}$, then a group of basic rocks (gabbro, basalts and diabase) with high contents of $\mathrm{Fe}$, $\mathrm{Ti}$ and $\mathrm{Cu}$. In granite, granodiorites, quartz diorites and diorite $\mathrm{Cu}, \mathrm{Ag}, \mathrm{Au}, \mathrm{Zn}, \mathrm{Cd}, \mathrm{Hg}$,
$\mathrm{Ge}, \mathrm{Sn}, \mathrm{Pb}, \mathrm{As}, \mathrm{Sb}, \mathrm{Bi}, \mathrm{Nb}, \mathrm{Ta}, \mathrm{S}, \mathrm{Se}, \mathrm{Te}$, $\mathrm{Mo}, \mathrm{W}, \mathrm{U}, \mathrm{Fe}, \mathrm{Co}$ and $\mathrm{Ni}$ are concentrated. Content of lead in magmatic rocks is changeable and depends on the character of these rocks. In the basic rocks, content of $\mathrm{Pb}$ is low and it rises with the acidity of magmatic rocks. So the content of $\mathrm{Pb}$ in granites is five times higher than the content in gabbro. Distribution of $\mathrm{Zn}$ in rocks of different composition is partially similar to the distribution of $\mathrm{Fe}$, beginning from the basic magmatic rocks percentage of $\mathrm{Zn}$ rises and in granodiorites achieves the highest values. According to the level of concentration, a distinct connection of $\mathrm{Cu}$ with basic rocks can be observed in some magmatic rocks. The connection of As with certain magmatic rocks refers to the medium acid rocks which have an increased content of that metal. For the influence of chemical composition of riverbank profiles in the basin area of the river Ibar, beside geological composition, the area of northern part of Kosovska Mitrovica is of special significance including the mines of $\mathrm{Pb}$ and $\mathrm{Zn}$ : Crnac, Belo brdo (pit excavation) and Koporiš surface excavation, flotation in Leposavić and me-tallurgy complex which includes the chemical industry of $\mathrm{Zn}$ and the Factory of batteries. Anthropogenic influence is the strongest at location of 
riverbank profile 5 in which there are extremely high concentrations of $\mathrm{Pb}, \mathrm{Zn}, \mathrm{Cu}$, As and $\mathrm{Cd}$ (Figures 3-6) and $\mathrm{Fe}$ in Ahorizon, OB-overbank sediment and Sstream sediment and it is located down stream from Kosovska Mitrovica. The highest content of ${ }^{238} \mathrm{U},{ }^{232} \mathrm{Th},{ }^{40} \mathrm{~K}$ i ${ }^{226} \mathrm{Ra}$ are found in the stream sediments at location 5, downstream from Kosovska Mitrovica (Table 3).

Table 3 Contents of natural radionuclides ${ }^{238} \mathrm{U},{ }^{232} \mathrm{Th},{ }^{40} \mathrm{~K},{ }^{226} \mathrm{Ra}$ in the riverbank profiles from the spring part of the river Ibar (location 6) till the mouth in the West Morava (location 1)

\begin{tabular}{|c|c|c|c|c|c|c|}
\hline River Ibar & & ${ }^{238} \mathrm{U}, \mathrm{ppm}$ & ${ }^{232} \mathrm{Th}, \mathrm{ppm}$ & ${ }^{40} \mathrm{~K}, \%$ & ${ }^{226} \mathrm{Ra}, \mathrm{ppm}$ & $\mathbf{T h} / \mathbf{U}$ \\
\hline & $\mathbf{A}$ & 2.68 & 6.65 & 1.25 & 0.000090 & 2.48 \\
\hline \multirow{3}{*}{ Location 1} & OB & 2.09 & 8.32 & 1.42 & 0.000071 & 3.98 \\
\hline & $\mathbf{S}$ & 2.45 & 7.89 & 1.53 & 0.000083 & 3.22 \\
\hline & A & 0.43 & 0.89 & 0.13 & 0.000015 & 2.05 \\
\hline \multirow[t]{3}{*}{ Location 2} & OB & 1.89 & 7.60 & 1.15 & 0.000064 & 4.03 \\
\hline & $\mathbf{S}$ & 2.48 & 7.43 & 1.23 & 0.000084 & 3.00 \\
\hline & A & 2.28 & 7.75 & 1.50 & 0.000077 & 3.40 \\
\hline \multirow[t]{3}{*}{ Location 3} & OB & 2.10 & 8.34 & 1.47 & 0.000071 & 3.97 \\
\hline & $\mathbf{S}$ & 2.16 & 6.14 & 1.18 & 0.000073 & 2.84 \\
\hline & $\mathbf{A}$ & 1.70 & 6.31 & 1.33 & 0.0000574 & 3.71 \\
\hline \multirow[t]{3}{*}{ Location 4} & OB & 1.53 & 5.09 & 1.24 & 0.0000516 & 3.33 \\
\hline & $\mathbf{S}$ & 2.26 & 6.54 & 1.39 & 0.0000763 & 2.89 \\
\hline & $\mathbf{A}$ & 2.15 & 3.65 & 1.08 & 0.0000726 & 1.70 \\
\hline \multirow{4}{*}{ Location 5} & OB & 2.61 & 2.95 & 0.70 & 0.0000881 & 1.13 \\
\hline & OB & 1.52 & 3.58 & 0.68 & 0.0000513 & 2.36 \\
\hline & $\mathbf{S}$ & 6.27 & 18.30 & 2.70 & 0.0002117 & 2.92 \\
\hline & A & 1.14 & 5.51 & 1.36 & 0.0000476 & 3.91 \\
\hline \multirow[t]{2}{*}{ Location 6} & OB & 1.31 & 5.32 & 1.19 & 0.0000442 & 4.06 \\
\hline & $\mathbf{S}$ & 1.13 & 3.53 & 1.26 & 0.0000381 & 3.12 \\
\hline
\end{tabular}

The origin of anomalous concentrations of ${ }^{238} \mathrm{U},{ }^{232} \mathrm{Th},{ }^{40} \mathrm{~K},{ }^{226} \mathrm{Ra}$ can be associated with a fluvial transport of radioactive elements from Kosovo area by the river Sitnica, which flows into the river Ibar, upstream from location 5 (Figure 1). The presence of lead and zinc mines in the immediate vicinity (upstream of location 5) requires further research, but in the regional perception of the ecological status of the region, an analysis of content the chemical elements in the riverbank profile is evident and significant. Sampling methodology provides representative data in a regional sense and it is important in the selection of geopathogenic zones of influence the natural radionuclides [15] and other toxic elements.

\section{CONCLUSION}

Geochemical mapping of riverbank profiles which includes: A-horizon, OB-over- bank sediment and S-stream sediment, is of significance for proper determination of scattering halos, formed depending on geological composition or anthropogenic influence. The applied sampling methodology of riverbank profiles and analytical methods are of special relevance in researching the mineral raw materials and making regional, semidetail and detail geochemical maps. Correlation of contents the chemical elements in the main rocks and defined anthropogenic influence in the riverbank profile, define the state in the living environment. By making geochemical maps in different environments of the geosphere, a data base was formed for defining the state of the living environment in the preindustrial and postindustrial period, and also monitoring was established. The research results are multipurpose, especially for marking the area of biogeochemical endemia, making of 
geomedicine maps, researching the mineral raw materials and the other study multidisciplinary researches.

\section{REFERENCES}

[1] R. T. Ottesen, J. Bogen, B. Bølviken, T. Volden, Overbank sediment: A Representative Sample Medium for Regional Geochemical Mapping, Journal of Geochemical Exploration, 32 (1989), 257-277.

[2] M. G. Macklin, Metal Contamination of Soils and Sediments: A Geographical Perspective. In: Newson, M.D. (Ed.), Managing the Human Impact on the Natural Environment: Patterns and Processes, London, Belhaven Press, 1992, 172-195.

[3] M. G. Macklin, J. Ridgway, D. G. Passmore, B.T. Rumsby, The Use of Overbank Sediment for Geochemical Mapping and Contamination Assessment: Results from Selected English and Welsh Floodplains, Applied Geochemistry 9 (1994), 689-700.

[4] B. Bølviken, J. Bogen, A. Demetriades, W. De Vos, J. Ebbing, R. Hindel, R.T. Ottesen, R. Salminen, O. Schermann, R. Swennen. Final Report of the Working Group on Regional Geochemical Mapping 1986-1993. Forum of European Geological Surveys (foregs), Geological Survey of Norway Open File Report, 1993, No. 93-092.

[5] V. Gordanić, D. Milovanović, M. Vidović, S. Rogan, I. Trajković, Geochemical Map of Eastern Serbia in 1:1000000 and Application in Defining the Ecological Status of Selected Areas, Proceedings of the 17th Meeting of the Association of European Geological Societies - MAEGS 17, Serbian Geological Society, Belgrade, Serbia, 2011, 187-191.

[6] V. Gordanić, A. Ćirić, D. Jovanović, The Use Overbank Sediments Data for Geochemical Mapping and Contamination Assessment: Results from Selected Floodplains of Serbia, Goldschmidt Conference Abstracts "Gold- shmidt 2007“، Cologne, Germany, Geochimica et Cosmochimica Acta, 71 (2007), 15, 1, A346.

[7] V. Gordanić, A. Ćirić, D. Jovanović, Regional Geochemical Mapping Ecological Significance. Goldschmidt Conference Abstracts "Goldshmidt 2008“, Vancouver, Canada, Geochimica et Cosmochimica Acta, 72 (2008), 12, A321.

[8] V. Gordanić, V. Spasić-Jokić, Geochemical indicators in identirication of geopathogenic zones of natural radioactivity. MD-Medical Data, 5 (2013), 2, 121-124.

[9] R. L. Folk, The distinction between grain size and mineral composition in sedimentary rock nomenclature. Journal of Geology 62 (1954), 4, 344-359.

[10] J. Green, Geochemical Table of the Elements for 1959, Geological Society of America Bulletin 70 (1959), 11271184.

[11] M. Fleischer, The Abundance and Distribution of the Chemical Elements in the Earth Crust, Journal of Chemical Education, 31 (1954), 9, 446-455;

[12] A. P. Vinogradov, Regularity of Distribution of Chemical Elements in the Earth Crust. Geochemistry, 1(1956) 143.

[13] R. Marković, J. Stevanović, M. Gvozdenović, J. M. Jakšić, Treatment of Waste Sulfuric Acid Copper Electrolyte, Mining and Metallurgy Engineering Bor, 3 (2014), 141-152.

[14] L. Zupunski, V. Spasic-Jokic, V. Gordanic, Chapter IX: Low Dose Exposure to Radionuclides in Soil, In: Gerada, J.G. (Ed.), Radionuclides: Sources, Properties and Hazards, New York, Nova Science Publishers, Inc., 2012, 151-170.

[15] V. Spasic-Jokic, Lj. Zupunski, Z. Mitrovic, B. Vujicic, I. Zupunski, Lj. Jankovic-Mandic, V. Gordanic, Environmental Risk of Natural Radiation Sources, 2011 IEEE International Workshop on Medical Measurements and Applications Proceedings (MeMeA), Bari, Italia, 2011, 638-641. 


\begin{tabular}{ll}
\hline \hline INSTITUT ZA RUDARSTVO I METALURGIJU BOR & ISSN: 2334-8836 (Štampano izdanje) \\
UDK: 622 & ISSN: 2406-1395 (Online) \\
\hline \hline
\end{tabular}

Vojin Gordanić, Milka Vidović, Ivana Trajković, Saša Rogan *

\section{GEOHEMIJSKO KARTIRANJE OBALSKIH PROFILA U SLIVNOM PODRUČJU REKE IBAR: ULOGA U USPOSTAVLJANJU GEOHEMIJSKE OSNOVE ZA PROCENU ANTROPOGENOG UTICAJA NA ŽIVOTNU SREDINU**}

\section{Izvod}

Kartiranje obalskih profila u slivnom podrućju reke Ibar vršeno je u cilju izrade geohemijske karte Srbije 1:1000000. U ovom području se nalaze ležišta olova i cinka, a karakteriše ga veoma složen geološki sastav. Mreža uzorkovanja na izabranim lokacijama obalskih profila prilagođena je morfološkim i hidrografskim karakteristikama terena. Na svakom profilu prikupljeni su uzorci iz Ahorizonta, overbank sedimenta i aktivnog strim sedimenta, prateći promene litoloških članova, $u$ skladu sa metodologijom WEGS (Western European Geological Surveys).

Sačuvani geohemijski zapis u overbank sedimentu je od posebnog značaja za korelaciju rezultata hemijskih elemenata u površinskom delu (A-horizont) $i$ aktivnog savremenog strim sedimenta. $U$ analitičkom postupku, pored određivanja sadržaja $\mathrm{Pb}, \mathrm{Zn}, \mathrm{Cu}, \mathrm{Co}, \mathrm{Ni}, \mathrm{Cr}, \mathrm{Sb}, \mathrm{V}, \mathrm{Cd} i$ drugih elemenata, vršena su radiometrijska ispitivanja sadržaja $U^{238}, T^{232} i K^{40}$, kao i odgovarajuće sedimentološke analize. Na bazi rezultata geohemijske prospekcije formirana je baza podataka koja čini osnovu za procenu antropogenog uticaja na životnu sredinu ruralnih naselja u slivnom području reke Ibar. U skladu sa geološko-strukturnim i morfološkim karakteristikama terena, rezultati su primenjivi u istraživanju mineralnih sirovina, u poljoprivredi, šumarstvu, geomedicini i sl.

Ključne reči: overbank, strim sedimenti, A-horizont, geohemijsko kartiranje, obalski profil

\section{UVOD}

Overbank sediment (materijal deponovan u aluvijalnoj ravnici izvan drenažnog kanala) se obično koristi prilikom izrade regionalnih geohemijskih karata [1]. Proučavanjima u Velikoj Britaniji pokazano je da postoji ,tesna veza“ između rudničke kontaminacije i sadržaja metala u savremenim overbank sedimentima [2,3]. Primenu OB-overbank sedimenta kao sredine pogodne za izradu geohemijskog atlasa zapadne Evrope i definisanje antropogenog uticaja na životnu sredinu, zastupali su Bolviken i autori [4]. Prilikom izrade regionalne geohemijske karte 1:1000000 Srbije [5], korišćen je overbank sediment, a za istraživanja su korišćene slivne površine od $60-600 \mathrm{~km}^{2}$. Značaj overbank sedimenta u definisanju ekološkog statusa i izradi

\footnotetext{
* Univerzitet u Beogradu, Naučna ustanova Institut za hemiju, tehnologiju i metalurgiju,Centar za ekologiju i tehnoekonomiku, Njegoševa 12,Beograd, e-mail: trajkovicivana@yahoo.com

** Ovaj rad je realizovan uz podršku Ministarstva prosvete, nauke i tehnološkog razvoja Republike Srbije (projekat OI 176018: „, Geološka i ekotoksikološka istraživanja u identifikaciji geopatogenih zona toksičnih elemenata u akumulacijama vode za piće- istraživanje metoda i postupaka smanjivanja uticaja biogeohemijskih anomalija")
} 
regionalne geohemijske karte Srbije prikazan je na lokacijama obalskih profila (Ahorizonta, OB-overbank sedimenta i S-strim sedimenta) $[6,7,8]$. Pošto overbank sedimenti pored izrade geohemijske karte služe za definisanje stanja antropogenog uticaja na životnu sredinu, $u$ istraživanjima se obično primenjuje metodologija WEGS (Western European Geological Surveys). Iz tih razloga izabrano je slivno područje reke Ibar u kome se nalaze ležišta olova i cinka, i koje karakteriše veoma složen geološki sastav. Geohemijsko kartiranje obalskih profila sliva reke Ibar, obuhvatilo je deo područja vardarske zone i unutrašnjih dinarida. Izdvajaju se dva kompleksa: Vulkanska zona Kopaonika i područje planine Rogozne.

Vulkanska zona Kopaonika nalazi se sa obe strane reke Ibar, u dužini oko $60 \mathrm{~km} \mathrm{i}$ širine $35 \mathrm{~km}$ (pravca pružanja SSZ-JJI), zahvatajući prostor od ušća u zapadnu Moravu na severu do Leposavića na jugu. Ona se nastavlja na vulkanogeni kompleks rudnika $\mathrm{Pb}$ i $\mathrm{Zn}$,Trepča“, a prošla je kroz tri faze vulkanske aktivnosti: predplutonsku fazu (dalto-andeziti, praćeni većim poja- vama vulkanskih breča, tufova i tufita), sinplutonsku (granodioriti, kvarcmonconiti i kvarcdioriti sa pojavama vulkanskih breča, tufova i tufita) i postplutonsku fazu (bazalti i andezit bazalti). Vulkaniti i piroklastiti Rogozne se razlikuju od kopaoničkih samo mlađim postplikativnim fazama vulkanske aktivnosti. Od većih strukturnih formi, od značaja je strukturna zona Studenice čiji sistem razloma ide tokom reke Studenice (pritoke Ibra), a u ibarskom ultramafitskom kompleksu se teško prati.

\section{MATERIJALI I METODE}

Slivno područje reke Ibar sa svojim pritokama - rekama Ribnica, Lopatnica, Studenica, Raška, Ljudska, Jošanica, Drenska, Kozareva, Vidrenjak, obuhvata površinu od oko $7000 \mathrm{~km}^{2}$. U fazi regionalne geohemijske prospekcije, izvršeno je kartiranje obalskih profila aluvijalnih ravnica, rečnih dolina dela južne i centralne Srbije. Mreža uzorkovanja prilagođena je morfološkim i hidrografskim karakteristikama terena, u skladu sa razmerom karte 1:1000000 (Slika 1).

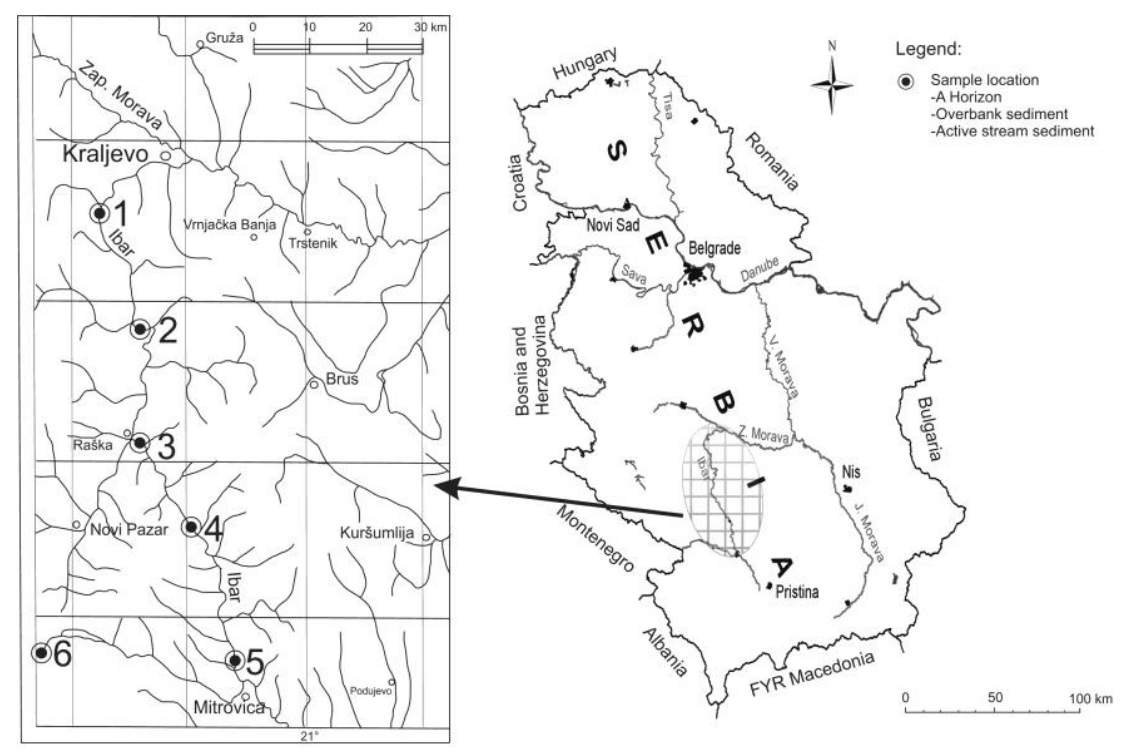

Sl. 1. Geohemijska karta sa lokacijama uzorkovanja 
Prema preporuci WEGS-a (ZapadnoEvropske Geohemijske Asocijacije), na izabranim lokacijama (prikazanim na Slici 1), prikupljeni su uzorci iz:

- A - horizonta, na dubini do $20 \mathrm{~cm}$ blizu površine, koji je zagađen uticajem čoveka, a težina uzorka je iznosila $5 \mathrm{~kg}$;

- OB - podpovršinski materijal „overbank sediment" uzorkovan na dubini 1-1,5 m, u skladu sa litološkim promenama deponovanih sedimenata, pri čemu je težina uzorka iznosila $5-15 \mathrm{~kg}$;

- S - savremeni aktivan strim sediment, koji je uzorkovan radi korelacije sa rezultatima iz obalskih profila formiranih $\mathrm{u}$ preindustrijskom dobu a težina uzorka je iznosila $5 \mathrm{~kg}$.

Uzorci su sušeni na temperaturi od $80^{\circ} \mathrm{C}$ i prosejani na sitima dimenzije do $2 \mathrm{~mm}$; od 2-0,5 mm;0,5-0,18 mm; 0,18-0,125 mm. Od frakcija manjih od $0,125 \mathrm{~mm}$ izvršena su laboratorijska ispitivanja. Od metoda hemijske analize, primenjene su: atomsko apsorpciona spektrofotometrija (AAS) i ICP-AES (Indukovano spregnuta plazma-atomskoemisiona spektrofotometrija). Uzorci su pripremani otvorenom digestijom sa mineralnim kiselinama: sa „carskom vodom“ (smeša $\left.\mathrm{HCl}: \mathrm{HNO}_{3}=3: 1\right) \mathrm{za}: \mathrm{Ag}, \mathrm{Au}, \mathrm{Bi}, \mathrm{Cd}, \mathrm{Co}$, $\mathrm{Cu}, \mathrm{Mo}, \mathrm{Ni}, \mathrm{Pb}, \mathrm{Sb}, \mathrm{V}$ i $\mathrm{Zn}$; sa „modifikovanom carskom vodom" za: P i S i razlaganjem sa $\mathrm{HF}, \mathrm{NH}_{3}, \mathrm{HClO}_{4}$ za: $\mathrm{B}, \mathrm{Ba}, \mathrm{Be}$, $\mathrm{Cr}, \mathrm{Cs}, \mathrm{Li}, \mathrm{Rb}$ i $\mathrm{Sr}$.

$\mathrm{U}$ analitičkom postupku korišćeni su međunarodni geohemijski standardi granita G-1 i dijabaza W-1, a uzorci su i proveravani u nekoliko laboratorija. U svim uzorcima vršena su sedimentološka, spektrohemijska, radiometrijska i delimično minerološka ispitivanja. U prikupljenim uzorcima sa niskim sadržajem $U(<50$ ppm), određeni su sadržaji ukupnog U, ${ }^{232} \mathrm{Th}$ i ${ }^{40} \mathrm{~K}$. Merenja su izvršena pomoću scintilacionog detektora 4" x 4", firme Bikron sa kristalom od NaI sa multiplikativnim analizatorom (MCA; 4096 kanala) tipa „ORTEC-7500“. Analize se zasnivaju na merenju zračenja visokih energija (0-3 meV). Za kalibraciju spektra i proračun koncentracije prirodnih radionuklida, korišćeni su standardi rude urana $\mathrm{U}$ i torijuma Th, „New Bruncvick Laboratorija“ (USAEC), NBL. No. 103 0,005\% U $i$ NBL. No. 107 0,10\% Th. Kao standard kalijuma, upotrebljen je kalijum-hlorid (r.a.).

\section{REZULTATI I DISKUSIJA}

U skladu sa geološkim karakteristikama terena u obalskom profilu, sačuvan je geohemijski zapis elemenata koji odslikavaju sastav izvorišnog materijala, a koji je deponovan $\mathrm{u}$ fluvijalnoj ravni slivnog područja reke Ibar. $\mathrm{Na}$ osnovu rezultata granulometrijskih i hemijskih ispitivanja, prikupljeni sedimenti depozita izabranih lokacija determinisani su prema klasifikaciji Folk-1954 (Slika 2):

- A - horizont kao: peskoviti alevrit, alevritski pesak, pesak, alevritsko peskoviti šljunak;

- OB - overbank sediment kao: peskoviti alevrit, alevritski pesak, šljunkoviti alevritski pesak, pesak;

- S - strim sediment kao: šljunkovito alevritski pesak, šljunkoviti pesak, peskoviti šljunak, krupnozrni pesak, šljunak.

Geohemijski zapis obalskih profila na izabranim lokacijama: 1, 2, 3, 4, 5, 6 prikazan je u Tabeli 1, a mesta uzorkovanja su predstavljena na geohemijskoj karti (Slika 1). 


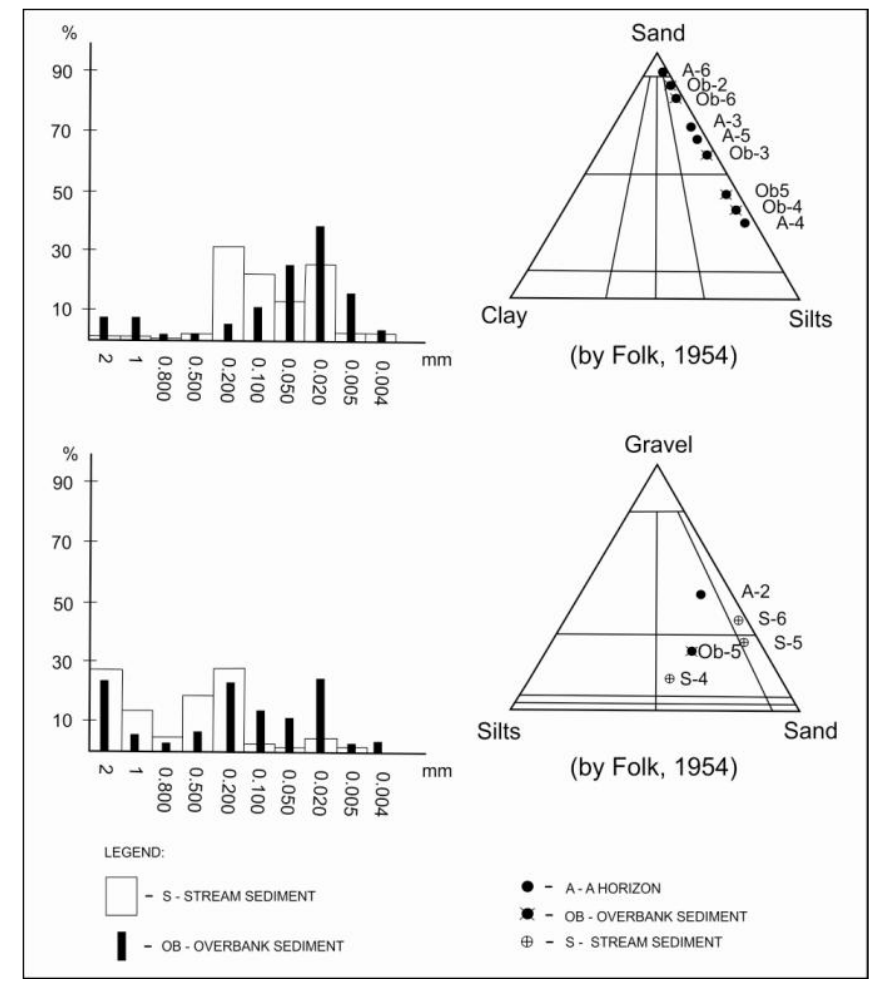

S1. 2. Histogram distribucija frakcija u profilu reke Ibar i klasifikacija po Folku [9]

Tabela 1. Sadržaj elemenata u obalskim profilima od izvorišnog dela reke Ibar (lokacija 6) od ušća u Zapadnu Moravu (lokacija 1).

\begin{tabular}{|c|c|c|c|c|c|c|c|c|}
\hline Reka Ibar & & $\begin{array}{l}\mathbf{P b}, \\
\text { ppm }\end{array}$ & $\begin{array}{l}\text { Zn, } \\
\text { ppm }\end{array}$ & $\begin{array}{l}\mathrm{Cu}, \\
\text { ppm }\end{array}$ & $\begin{array}{r}\text { Cd, } \\
\text { ppm }\end{array}$ & $\begin{array}{l}\text { As, } \\
\text { ppm }\end{array}$ & $\begin{array}{l}\text { Fe, } \\
\text { ppm }\end{array}$ & $\begin{array}{l}\text { Uu, } \\
\text { ppm }\end{array}$ \\
\hline \multirow{3}{*}{ Lokacija 1} & $\bar{A}$ & 173 & 276 & 32 & 0.9 & - & - & - \\
\hline & OB & 190 & 1333 & 28 & 3.3 & - & - & - \\
\hline & $\mathbf{S}$ & 127 & 1220 & 27 & 3.6 & - & - & - \\
\hline \multirow{3}{*}{ Lokacija 2} & $\mathbf{A}$ & 85 & 65 & 35 & 1.2 & 13.9 & 31400 & 4.6 \\
\hline & OB & 95 & 78 & 35 & 1.3 & 9.8 & 35700 & 4.8 \\
\hline & $\mathbf{S}$ & 90 & 81 & 35 & 1.3 & 11.6 & 42800 & 4.0 \\
\hline \multirow{3}{*}{ Lokacija 3} & A & 110 & 81 & 35 & 0.9 & 8.8 & 22500 & 5.6 \\
\hline & OB & 110 & 25 & 35 & 0.6 & 11.5 & 18700 & 9.8 \\
\hline & $\mathbf{S}$ & 60 & 72 & 35 & 1.2 & 8.2 & 25000 & 18.2 \\
\hline \multirow{3}{*}{ Lokacija 4} & $\mathbf{A}$ & 210 & 311 & 68 & 1 & 3.5 & 70525 & 3.5 \\
\hline & OB & 390 & 392 & 61 & 2 & 7.8 & 72540 & 3.5 \\
\hline & $\mathbf{S}$ & 530 & 712 & 100 & 4 & 17.4 & 76895 & 3.2 \\
\hline \multirow{4}{*}{ Lokacija 5} & $\mathbf{A}$ & 3500 & 3710 & 345 & 26 & 78.8 & 150150 & 0.4 \\
\hline & OB & 4000 & 297 & 491 & 11 & 36.3 & 241800 & - \\
\hline & OB & 3070 & 4995 & 542 & 26 & 112 & 108875 & 4.2 \\
\hline & $\mathbf{S}$ & 700 & 1703 & 79 & 13 & 7.5 & 80145 & 7.7 \\
\hline \multirow{3}{*}{ Lokacija 6} & A & 85 & 99 & 68 & 1 & 10.1 & 59020 & 3.0 \\
\hline & OB & 35 & 101 & 47 & $\square 1$ & 7.0 & 45045 & 6.7 \\
\hline & $\mathbf{S}$ & 100 & 88 & 44 & 1.0 & 3.2 & 34250 & 3.2 \\
\hline
\end{tabular}


Rezultati varijacije sadržaja $\mathrm{Pb}, \mathrm{Zn}$, za A - horizont, OB - overbank sedimenta $\mathrm{Cu}, \mathrm{Cd}$, As prikazani su na dijagramima i S - strim sedimenta (Slike 3-6). za svaki obalski profil po lokacijama

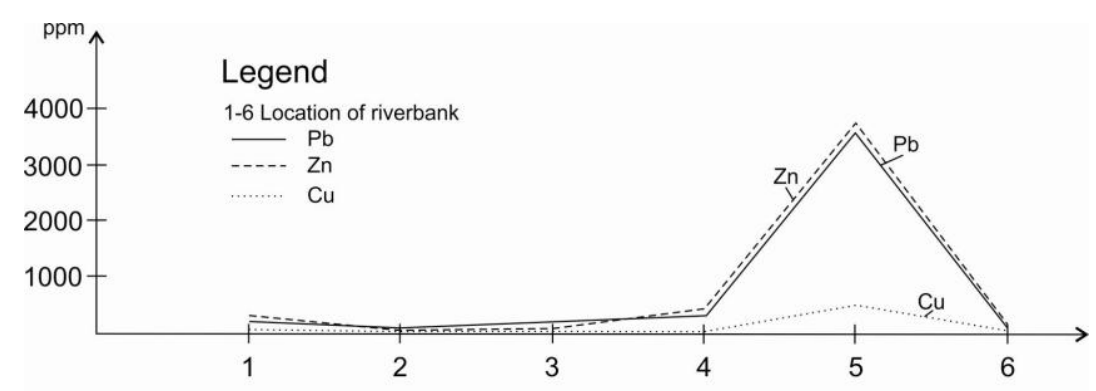

SI. 3. Varijacije sadržaja Pb, Zn i Cu u A-horizontu na lokacijama reke Ibar

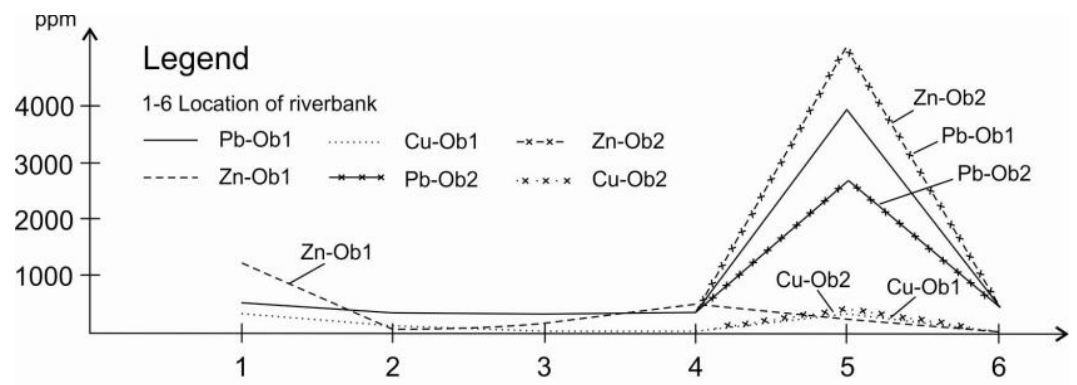

SI. 4. Varijacije sadržaja $\mathrm{Pb}$, Zn i Cu u OB-overbank sedimentima reke Ibar

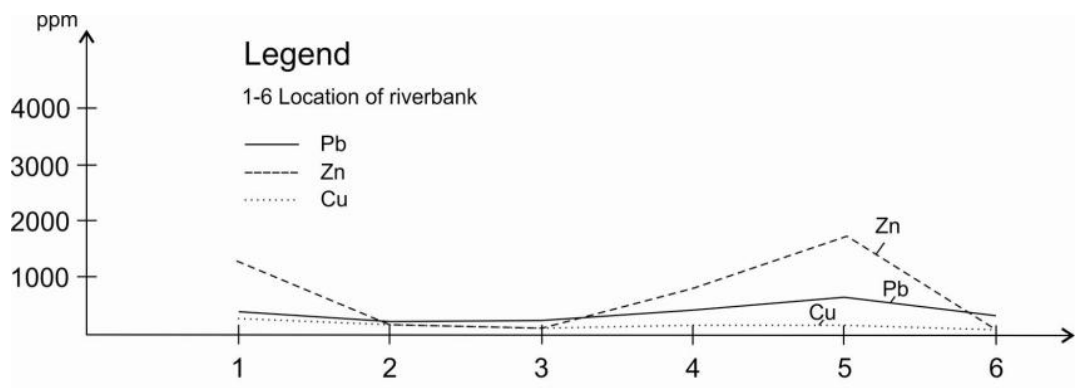

SI. 5. Varijacije sadržaja $\mathrm{Pb}, \mathrm{Zn}$ i Cu u S-strim sedimentima reke Ibar

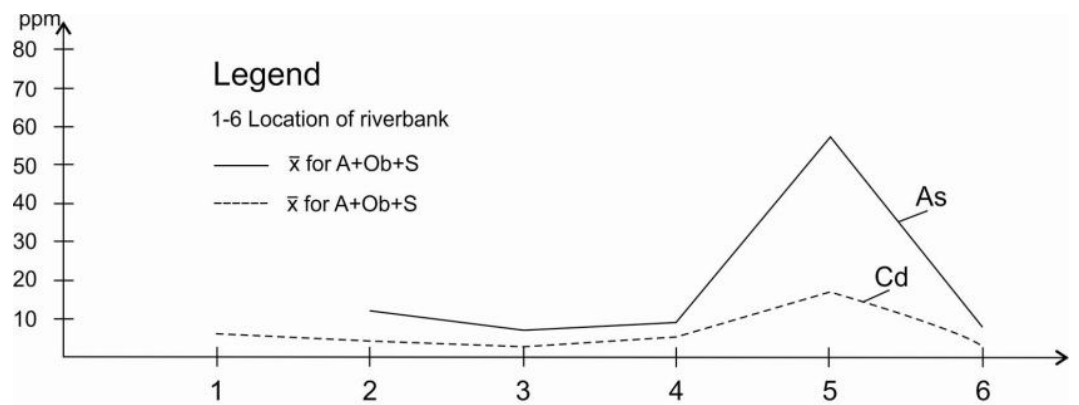

SI. 6. Varijacije sadržaja As i Cd u obalskim profilima reke Ibar 
Anomalne koncentracije $\mathrm{Pb}, \mathrm{Zn}, \mathrm{Cu}$, $\mathrm{Cd}$, As i Fe su dvojakog porekla: iz stena u kojima je fon visokih vrednosti (Tabela 2) i elemenata koji potiču od rude (rudničke halde, stari rudarski radovi), metalurški procesi, agrohemijska jedinjenja bogata metalima, materijal za nasipanje puteva, otpadne vode $\mathrm{i}$ dr.

Tabela 2. Prosečan kontrast između sadržaja metala u neorudnjenoj zoni i u perifernoj rudi

\begin{tabular}{|l|c|c|c|}
\hline Glavni metali & $\begin{array}{c}\text { (A) Sadržaj u magmatskim } \\
\text { stenama (ppm) }\end{array}$ & $\begin{array}{c}\text { (B) Sadržaj u rudama } \\
\text { koje se obrađuju (ppm) }\end{array}$ & $\begin{array}{c}\text { Kontrast odnos } \\
\text { B/A }\end{array}$ \\
\hline Olovo, $\mathrm{Pb}$ & $16^{\mathrm{a}}$ & $50000^{\mathrm{b}}$ & 3000 \\
\hline $\mathrm{Cink}, \mathrm{Zn}$ & $80^{\mathrm{a}}$ & $80000^{\mathrm{b}}$ & 1000 \\
\hline $\mathrm{Bakar}, \mathrm{Cu}$ & $70^{\mathrm{a}}$ & $10000^{\mathrm{b}}$ & 140 \\
\hline $\mathrm{Hrom}, \mathrm{Cr}$ & $2000^{\mathrm{c}}$ & $250000^{\mathrm{b}}$ & 125 \\
\hline $\mathrm{Nikl}, \mathrm{Ni}$ & $160^{\mathrm{d}}$ & 95 \\
\hline \\
${ }^{\mathrm{a}}[10]$ \\
${ }^{\mathrm{b}}$ Rezultati za Pb, Zn, Cu [11] \\
${ }^{\mathrm{c}}$ Prosečna vrednost u ultrabaznim stenama [12] \\
${ }^{\mathrm{d}}$ Prosečna vrednost u gabru [13]
\end{tabular}

Kontrasti u sadržajima metala između sekundarnih geohemijskih anonmalija i normalnog fona je $\mathrm{u}$ zavisnosti od mnogih faktora: kontrasta između rude i okolne stene, relativne mobilnosti elemenata $u$ sredini rasejavanja, razblaženjem koncentracije sterilnim materijalom. Za različite tipove mineralnih ležišta, primarni kontrast varira u širokim granicama (Tabela 2). Primarni kontrast više održavaju imobilni elementi $(\mathrm{Pb})$ nego mobilni elementi $(\mathrm{Zn}$, $\mathrm{Cu}$ i U), koji su podložni izluživanju, čiji je stepen određen intenzitetom raspadanja, brzinom kretanja vode, veličinom $\mathrm{pH}$ vrednosti i mnogim drugim faktorima koji utiču na oblik rasejavanja [13]. U vodi je kontrast takođe u funkciji mobilnosti. Najveći kontrast pokazuju najmobilniji elementi. Mobilni elementi koji se talože kod relativno malih promena hemijskih i bioloških uslova pokazuju najoštriji kontrast u hidromorfnim anomalijama zemljišta i sedimenata [14].

$\mathrm{U}$ prospektovanom području sliva reke Ibar nalaze se matične stene visokih vrednosti fona. Najizrazitija je grupa ultrabazičnih stena (peridotiti, serpentiniti) sa visokim sadržajem $\mathrm{Cr}$, Ni, Co i Mg, zatim grupa bazičnih stena (gabro, bazalti i dijabazi) sa visokim sadržajem $\mathrm{Fe}$, Ti i $\mathrm{Cu}$.
U granitu, granodioritu, kvarcdioritu i dioritu su koncentrisani: $\mathrm{Cu}, \mathrm{Ag}, \mathrm{Au}, \mathrm{Zn}, \mathrm{Cd}, \mathrm{Hg}$, $\mathrm{Ge}, \mathrm{Sn}, \mathrm{Pb}, \mathrm{As}, \mathrm{Sb}, \mathrm{Bi}, \mathrm{Nb}, \mathrm{Ta}, \mathrm{S}, \mathrm{Se}, \mathrm{Te}$, Mo, W, U, Fe, Co i Ni. Sadržaj olova u magmatskim stenama je promenljiv i zavisi od karaktera tih stena. U bazičnim stenama, sadržaj $\mathrm{Pb}$ je nizak i raste sa kiselošću magmatskih stena. Tako je sadržaj $\mathrm{Pb} \mathrm{u}$ granitima pet puta veći od sadržaja u gabru. Raspodela $\mathrm{Zn}$ u stenama različitog sastava delimično je slična raspodeli Fe, počev od bazičnih magmatskih stena udeo $\mathrm{Zn}$ raste i u granodioritima dostiže najveće vrednostiPrema stepenu koncentracije u pojedinim magamatskim stenama zapaža se izrazita povezanost $\mathrm{Cu}$ sa bazičnim stenama. Povezanost As sa određenim magmatskim stenama odnosi se na srednje kisele stene, koje imaju povećan sadržaj tog metala. $\mathrm{Na}$ uticaj hemijskog sastava obalskih profila u slivnom području reke Ibar, pored geološkog sastava, od posebnog značaja je područje severnog dela Kosovske Mitrovice u kome se nalaze rudnici $\mathrm{Pb}$ i $\mathrm{Zn}$ : Crnac, Belo brdo (jamski kop) i Koporiš (površinski kop), zatim flotacija u Leposaviću i metalurški kompleks koji obuhvata hemijsku industriju $\mathrm{Zn}$ i fabriku akumulatora. Antropogeni uticaj najizraženiji je na lokaciji obalskog 
profila 5 u kome su izuzetno visoke koncentracije $\mathrm{Pb}, \mathrm{Zn}, \mathrm{Cu}$, As i Cd (Slike 3-6) i Fe u A-horizontu, OB-overbank sedimentu i Sstrim sedimentu a koji se nalaze nizvodno od
Kosovske Mitrovice. Najveći sadržaji ${ }^{238} \mathrm{U}$, ${ }^{232} \mathrm{Th},{ }^{40} \mathrm{~K}$ i ${ }^{226} \mathrm{Ra}$ nalaze se u strim sedimentu na lokaciji 5 nizvodno od Kosovske Mitrovice (Tabela 3).

Tabela 3. Uticaj prirodnih radionuklida ${ }^{238} \mathrm{U},{ }^{232} \mathrm{Th},{ }^{40} \mathrm{~K},{ }^{226} \mathrm{Ra}$ u obalskim profilima od izvorišnog dela reke Ibar (lokacija 6) od ušća u Zapadnu Moravu (lokacija 1)

\begin{tabular}{|c|c|c|c|c|c|c|}
\hline Reka Ibar & & ${ }^{238} \mathrm{U}, \mathrm{ppm}$ & ${ }^{232} \mathrm{Th}, \mathrm{ppm}$ & ${ }^{40} \mathrm{~K}, \%$ & ${ }^{226} \mathrm{Ra}, \mathrm{ppm}$ & $\mathrm{Th} / \mathrm{U}$ \\
\hline \multirow{3}{*}{ Lokacija 1} & $\mathbf{A}$ & 2.68 & 6.65 & 1.25 & 0.000090 & 2.48 \\
\hline & OB & 2.09 & 8.32 & 1.42 & 0.000071 & 3.98 \\
\hline & S & 2.45 & 7.89 & 1.53 & 0.000083 & 3.22 \\
\hline \multirow{3}{*}{ Lokacija 2} & $\mathbf{A}$ & 0.43 & 0.89 & 0.13 & 0.000015 & 2.05 \\
\hline & OB & 1.89 & 7.60 & 1.15 & 0.000064 & 4.03 \\
\hline & S & 2.48 & 7.43 & 1.23 & 0.000084 & 3.00 \\
\hline \multirow{3}{*}{ Lokacija 3} & $\mathbf{A}$ & 2.28 & 7.75 & 1.50 & 0.000077 & 3.40 \\
\hline & OB & 2.10 & 8.34 & 1.47 & 0.000071 & 3.97 \\
\hline & $\mathbf{S}$ & 2.16 & 6.14 & 1.18 & 0.000073 & 2.84 \\
\hline \multirow{3}{*}{ Lokacija 4} & $\mathbf{A}$ & 1.70 & 6.31 & 1.33 & 0.0000574 & 3.71 \\
\hline & OB & 1.53 & 5.09 & 1.24 & 0.0000516 & 3.33 \\
\hline & $\mathbf{S}$ & 2.26 & 6.54 & 1.39 & 0.0000763 & 2.89 \\
\hline \multirow{4}{*}{ Lokacija 5} & $\mathbf{A}$ & 2.15 & 3.65 & 1.08 & 0.0000726 & 1.70 \\
\hline & OB & 2.61 & 2.95 & 0.70 & 0.0000881 & 1.13 \\
\hline & OB & 1.52 & 3.58 & 0.68 & 0.0000513 & 2.36 \\
\hline & $\mathbf{S}$ & 6.27 & 18.30 & 2.70 & 0.0002117 & 2.92 \\
\hline \multirow{3}{*}{ Lokacija 6} & $\mathbf{A}$ & 1.14 & 5.51 & 1.36 & 0.0000476 & 3.91 \\
\hline & OB & 1.31 & 5.32 & 1.19 & 0.0000442 & 4.06 \\
\hline & S & 1.13 & 3.53 & 1.26 & 0.0000381 & 3.12 \\
\hline
\end{tabular}

Poreklo anomalnih koncentracija ${ }^{238} \mathrm{U}$, ${ }^{232} \mathrm{Th},{ }^{40} \mathrm{~K},{ }^{226} \mathrm{Ra}$ može se povezati sa fluvijalnim transportom radioaktivnih elemenata sa područja Kosova rekom Sitnicom, koja se uliva u reku Ibar uzvodno od lokacije 5 (videti sliku 1). Prisustvo rudnika olova i cinka u neposrednoj blizini (uzvodno od lokacije 5) zahteva detaljnija istraživanja, ali u regionalnom sagledavanju ekološkog statusa regiona evidentna je i značajna analiza rezultata sadržaja hemijskih elemenata $u$ obalskim profilima. Metodologija uzorkovanja obezbeđuje reprezentativne podatke $u$ regionalnom smislu i značajna je u izdvajanju geopatogenih zona uticaja prirodnih radionuklida [15] i drugih toksičnih elemenata.

\section{ZAKLJUČAK}

Geohemijsko kartiranje obalskih profila koga čine: A-horizont, OB-overbank sediment i S-strim sediment, od značaja je za pravilnu determinaciju oreola rasejavanja, formiranih u zavisnosti od geološkog sastava ili antropogenog uticaja. Primenjena metodologija uzorkovanja obalskih profila i analitičke metode su od posebnog značaja u istraživanju mineralnih sirovina i izradi regionalnih, poludetaljnih i detaljnih geohemijskih karata. Korelacija sadržaja hemijskih elemenata $u$ matičnim stenama i antropogeni uticaj definisan $\mathrm{u}$ obalskom profilu definišu stanje u životnoj sredini. Izradom geohemijskih karata $\mathrm{u}$ različitim sredinama geosfere, formira se osnova za praćenje definisanja stanja životne sredine $u$ preindustrijskom i postindustrijskom periodu i uspostavljanje monitoringa. Rezultati istraživanja su višenamenskog karaktera, naročito za evidentiranje područja biogeohemijske endemije, izrade geomedicinskih karata, istraživanje mineralnih sirovina i druga studijska multidisciplinarna istraživanja. 


\section{LITERATURA}

[1] R. T. Ottesen, J. Bogen, B. Bølviken, T. Volden, Overbank Sediment: A Representative Sample Medium for Regional Geochemical Mapping, Journal of Geochemical Exploration, 32 (1989), 257-277.

[2] M. G. Macklin, Metal Contamination of Soils and Sediments: A Geographical Perspective. In: Newson, M. D. (Ed.), Managing the Human Impact on the Natural Environment: Patterns and Processes, London, Belhaven Press, 1992, 172-195.

[3] M. G. Macklin, J. Ridgway, D. G. Passmore, B. T. Rumsby, The use of Overbank Sediment for Geochemical Mapping and Contamination Assessment: Results from Selected English and Welsh Floodplains, Applied Geochemistry 9 (1994), 689-700.

[4] B. Bølviken, J. Bogen, A. Demetriades, W. De Vos, J. Ebbing, R. Hindel, R.T. Ottesen, R. Salminen, O. Schermann, R. Swennen, Final Report of the Working Group on Regional Geochemical Mapping 1986-1993. Forum of European Geological Surveys (foregs), Geological Survey of Norway Open File Report, 1993, No. 93-092.

[5] V. Gordanić, D. Milovanović, M. Vidović, S. Rogan, I. Trajković, Geochemical mapp of Eastern Serbia in 1:1000000 and Application in Defining the Ecological Status of Selected Areas, Proceedings of the $17^{\text {th }}$ meeting of the Association of European Geological Societies - MAEGS 17, Serbian Geological Society, Belgrade, Serbia, 2011, 187-191.

[6] V. Gordanić, A. Ćirić, D. Jovanović, The use Overbank Sediments data for Geochemical Mapping and Contamination Assessment: Results from Selected Floodplains of Serbia, Goldschmidt Conference Abstracts ,Goldshmidt 2007“, Cologne, Germany, Geochimica et Cosmochimica Acta, 71 (2007), 15, 1, A346.
[7] V. Gordanić, A. Ćirić, D. Jovanović, Regional Geochemical Mapping Ecological Significance, Goldschmidt Conference Abstracts „Goldshmidt 2008“, Vancouver, Canada, Geochimica et Cosmochimica Acta, 72 (2008), 12, A321.

[8] V. Gordanić, V. Spasić-Jokić, Geochemical Indicators in Identirication of Geopathogenic Zones of Natural Radioactivity. MD - Medical Data, 5 (2013), 2, 121-124.

[9] R. L. Folk, The Distinction Between Grain Size and Mineral Composition in Sedimentary Rock Nomenclature. Journal of Geology 62 (1954), 4, 344359.

[10] J. Green, Geochemical Table of the Elements for 1959, Geological Society of America Bulletin 70 (1959), 11271184.

[11] M. Fleischer, The Abundance and Distribution of the Chemical Elements in the Earths Crust, Journal of Chemical Education, 31 (1954), 9, 446-455.

[12] A. P. Vinogradov, Regularity of Distribution of Chemical Elements in the Earth's Crust, Geochemistry, 1 (1956), $1-43$.

[13] R. Marković, J. Stevanović, M. Gvozdenović, J. M. Jakšić, Treatment of Waste Sulfuric Acid Copper Electrolyte, Mining and Metallurgy Engineering Bor, 3 (2014), 141-152.

[14] L. Zupunski, V. Spasic-Jokic, V. Gordanic, Chapter IX: Low Dose Exposure to Radionuclides in Soil, In: Gerada, J. G. (Ed.), Radionuclides: Sources, Properties and Hazards, New York, Nova Science Publishers, Inc., 2012, 151-170.

[15] V. Spasic-Jokic, Lj. Zupunski, Z. Mitrovic, B. Vujicic, I. Zupunski, Lj. Jankovic-Mandic, V. Gordanic, Environmental Risk of Natural Radiation Sources, 2011 IEEE International Workshop on Medical Measurements and Applications Proceedings (MeMeA), Bari, Italija, 2011, 638-641. 